The Geneva Papers on Risk and Insurance, 19 (No. 73, October 1994) 379-393

\title{
14th Annual Lecture of the Geneva Association: Uncertainty under the Welfare State - Policy-induced Risk - *
}

\author{
by Assar Lindbeck**
}

\begin{abstract}
Welfare state arrangements not only mitigate income risk, they also create new types of risks; we may call them "policy-induced risks". In some cases, market risk is replaced by the risk of changes in politically determined rules, "rule instability" for short. In other cases, welfare state arrangements change the character of market risk, and may even increase it. I call this "policy-induced market risk".

\section{Welfare state contributions to economic security}

A basic task of the welfare state is to reduce income risk. The most celebrated instrument for achieving this is, of course, social insurance, i.e., benefits connected to specific contingencies, financed by previous contributions. It is likely that social insurance has been successful in accomplishing this task in the sense that many individuals would not otherwise, on their own, have achieved an equally satisfactory reduction in income risk, and related smoothing of the income stream over the life cycle.

Social insurance is only one among many examples of government-operated systems that reduce income risks. Another is means-tested cash benefits to people in need ("social assistance"). There are also important elements of income insurance in the subsidies, and often also public sector provision, of social services like child care, education, health care, old-age care, and in some cases also of food and housing. Welfare state policies in these areas may, in fact, be regarded as a kind of nonactuarial service insurance for specific "merit goods" or basic needs, for which less uncertainty and more equality seem to be required by politicians than for the provision of cash income. (Tobin, 1970).

Moreover, as tax payments change automatically with factor income, rather than taxes being lump-sum payments, instability in disposable income, and hence income uncertainty,

* Paper presented at the 21st General Assembly of the Geneva Association, Stockholm, June 9 and 10, 1994. versity.

** Professor and Director of the Institute for International Economic Studies, Stockholm Uni-
\end{abstract}


are also mitigated through the tax system. Part of this reduction in income uncertainty, though only a modest part, is the result of the progressivity of the tax system. ${ }^{1}$

Other types of government interventions are more explicitly designed to reduce income uncertainty close to "the source". The most important example is probably macroeconomic "full employment policies", aimed at increasing general employment prospects, and hence at reducing factor-income uncertainty for the entire population of wage earners. Indeed, this type of policy may be seen as an attempt to remove macroeconomic income uncertainty, rather than as a method of sharing it as in the case of unemployment insurance. But to the extent that such policies result in government budget deficits, and thesc generate an accumulation of public sector debt over time, full employment policies will also include an element of intertemporal and intergenerational risk sharing and redistribution - though such sharing may sometimes turn out to be greater than future generations find comfortable.

Job security legislation is instead an attempt to reduce job and income risks for those who already have an employment contract - the so-called "insiders" in the labor market. Such legislation largely redistributes employment probabilities in favor of this group at the expense of so-called "outsiders", consisting mainly of unemployed workers and new entrants to the labor force (Lindbeck and Snower, 1988).

Price regulations may also be seen as attempts to reduce factor-income risk, though in this case in specific production sectors of the economy, in addition to the obvious ambitions to redistribute wealth among socio-economic groups - sometimes, as in agriculture in favor of producers, in other cases, as in housing in favor of consumers. Rent control and related tenant-security legislation are similar to job-security legislation in the sense that they accentuate the asymmetries of risk between those who have and those who do not have contracts, i. e., between insiders and outsiders in the housing market.

As these various welfare state contributions to mitigating uncertainty and providing income smothing are well known, I shall not dwell on them. Nor shall I deal with welfarestate induced contributions to the redistribution of wealth (life-time income) between individuals. I will instead concentrate on what is not usually realized, or has at least not been discussed to any large extent, namely that welfare state policies also tend to create risks; we may call them "policy-induced risks". There has been a tendency among economists to argue in favor of various welfare state arrangements on the basis of wellknown limitations in private insurance solutions, without due concern for various policy-induced risks in the connection to such welfare state arrangements. In some cases, market risk - in product, labor, capital or insurance market - is replaced by the risk of changes in politically determined rules, "rule instability" for short. In other cases, welfare state arrangements change the character of market risk, and may even increase it ; I will call this "policy-induced market risk".

\section{Rule instability}

\subsection{Politics and disincentive effects}

Let me start with unstable government-determined rules, i.e., rule instability. One trivial but important explanation for such instability is changes in political fashion in, for

\footnotetext{
${ }^{1}$ Hal Varian (1980), in particular, has emphasized that progressive taxation may be regarded as an income insurance system.
} 
instance, distribution or stabilization policies, reflecting changes either in preferences or in views of how society functions. Party-politics, i. e., competition for power between political parties, and lobbying by various interest groups with different outcomes on different occasions, are related factors behind such rule instability (Lindbeck, 1994 a).

Another explanation for the apparent instability of government-determined welfare state rules is related to the unavoidable disincentive effects of various welfare state programs and their financing. Not only tax wedges, but also moral hazard and cheating should then, of course, be considered (Lindbeck, 1994b). A basic reason why disincentive effects create unstable rules is that these effects cannot be fully anticipated in advance when welfare state rules are decided by politicians. Many disincentive effects also tend to be delayed because of gradual adjustments of individual behavior to changes in economic incentives. It takes time for citizens to adjust their work and saving behavior both to new tax disincentives and to new welfare state rules, such as conditions for sick-pay, unemployment benefits, disability pension, etc. (Lindbeck, 1994 b). As a result, it takes time also before politicians realize that reforms of, or retreats from, the welfare state are necessary - to boost the financial position of the government, to improve the functioning of the national economy, and perhaps even to save the welfare state from undermining its own economic foundations.

All this means that welfare state policies, through their effects on private behavior, feed back on contemporary and expected future political decision-making. This may, in turn, give rise to new adjustments of individual behavior, with new induced changes in the welfare state rules as a result - possibly with never-ending policy-induced uncertainties. Tax rules are a good example. The government tries to close loopholes in the tax system, but private individuals have strong incentives to find new loopholes, which forces the government to make new changes in the tax system, etc. in an endless chain of government-private interaction.

It is unavoidable that such developments result in heated public discussions about future reforms of the welfare state, and that these discussions in turn create uncertainties among citizens about the viability of earlier promised benefits, including the entitlements in the social insurance system. It is also likely that such discussions create political turmoil, which tends to increase the uncertainties even more about the future welfare state rules.

Instability of rules and regulations is not peculiar to welfare state programs. Similar problems exist for government activities in other areas. Instability is a particularly severe problem, however, with respect to the social insurance system, as citizens probably interpret many welfare state programs - such as pension-, disability-, sickness- and unemployment-insurance systems - as long-term contracts between the individual and the state. A 55year old, who starts to doubt that the government will fulfill its earlier promises regarding pension or health benefits, is hardly in a position to live his life all over again, for the purpose of accumulating private saving or buying voluntary insurance policies or annutities!

\subsection{Conflicts between generations}

A special reason for instability of welfare state rules is political conflicts between generations. One trivial example is that it is tempting for a majority of voters to introduce transfer systems, such as pensions, that overcompensate their own generation strongly, relative to subsequent generations. Indeed, such overcompensation has been standard in various countries in actually implemented pay-as-you-go pension system. This is often regarded as an advantage in the sense that a "full-blown" pension system can then be created very 
rapidly, by contrast to what is possible in an actuarially fair pension system. Such overcompensation is sometimes also defended by the argument that the favored generation is probably less affluent than subsequent generations are likely to be.

It is well known from the theoretical literature that future generations will not necessarilly lose on overcompensation to the first generations (Samuelson, 1958). But in reality, overcompensation has often been so large that subsequent generations tend, in fact, to lose. For instance, while the first generations in the pension system that was introduced in Sweden in 1960 (the ATP system) seem to have received about six times as much (in terms of capital value) as they paid into the system, generations born after 1943 will probably only receive about 80 percent, probably even less, of what they pay (Ståhlberg, 1988). Such large discrepancies in the treatment of different generations easily generate hostility among citizens toward previous generations, with the possibility that entitlements decided on earlier will not be fully respected in the future. This is bound to increase uncertainty about the entitlements.

The distributional effects of a pay-as-you-go social insurance system on different generations are also quite sensitive to long-term changes in productivity growth and demography. Suppose, for instance, that pensions are tied to the previous income paths of citizens. A slow down in labor-productivity growth, or a fall in the relative share of the population of working age, would then mean higher fees for the active population, with a fall in their lifetime income as a result. If fees are fixed instead, pensioners will get lower income. In both cases, political conflicts between generations are likely, along with emerging uncertainty about social security rules in the future. Indeed, even unjustified beliefs that subsequent generations may not grant previously enacted entitlements will increase economic uncertainty.

A related reason for emerging doubts about the viability of social security entitlements is increased deficits in the government budget - another source of intertemporal and intergenerational conflicts. Such developments may even be a result of welfare state policy itself, as politicians may not be able to finance the welfare state spending programs by higher fees or taxes. The reason may be an unexpected increase in the number of beneficiaries, or an erosion of the tax base because of various disincentive effects on the national economy of welfare state programs and their financing.

Deficits that are initially created by cyclical factors may also create doubts about the long-term viability of public sector finances, as cyclical deficits may gradually be transformed into structural ones. One reason is that it may be politically impossible to bring about sufficiently large compensating cyclical surpluses in ensuing booms. Another reason is that cyclical increases in unemployment, at least in Western Europe, tend to raise the unemployment rate for a long period of time - the notorious unemployment persistence phenomenon. As a result, not only will various tax bases be undermined; many citizens who leave the employment ranks will be financed by the government for a long period of time - in some cases for the rest of their lives. For these various reasons, a temporary (negative) macroeconomic shock may contribute to doubts about the long-term viability of various welfare state programs. This is exactly what happened in Sweden in the early 1990s.

\subsection{Rule instability in public versus private sector}

It is a commonplace that moral hazard is a serious problem for the welfare state. In my 
judgment, it is the basic dilemma of the welfare state, as people gradually learn to exploit various types of welfare state benefits, with a tendency for the number of beneficiaries to increase over time. Moral hazard is, however, not unique for government-operated systems. Indeed, moral hazard, often combined with adverse selection, is often referred to as a reason why private market solutions to insurance problems do not function properly, and hence why governments have implemented mandatory social insurance system instead. But while mandatory social insurance solves problems of adverse selection, it would seem that moral hazard is an even more serious problem for government-operated systems than for private insurance. One trivial explanation is that governments tend to organize benefit systems precisely in those areas where moral hazard, sometimes combined with adverse selection, is so pervasive that private insurance organizations choose not to enter. Unemployment benefits and disability pensions are obvious examples. Benefits in connection with motherhood, including benefits for single mothers, are another.

Moreover, while moral hazard is a "simple" principal-agent problem in the private sector - the insurer being the principal and the insured the agent - there is a "double" principal-agent problem in public-sector insurance systems, as the government, in its turn, is an agent for another principal, namely the voter (or taxpayer). One reason why the latter principal-agent problem is so severe is that it is difficult for the voter (the principal in this case) to express his opinion on specific issues, such as some aspects of the social insurance system, because elections concern a conglomerate of issues. Another reason is that politicians (the agents in this case) do not usually have very strong incentives to mitigate moral hazard. One explanation is that the consequences of moral hazard are often both controversial and delayed to a distant future when today's politicians are no longer in office.

The political process, therefore, easily results in more generous benefits than would be contemplated in the case of a well-informed tradeoff between risk sharing and efficient incentives. It is also, for reasons of party-politics, difficult for politicians to reduce benefit levels later on, when it is obvious that many more citizens than initially expected have adjusted their behavior to receive welfare state benefits.

These assertions about the pervasiveness of moral hazard in welfare state systems do not deny that the government may in some cases be able to mitigate moral hazard by methods that are not available to private agents. Taxes on cigarettes and gasoline, for instance, discourage behavior that raises the costs of life and disability insurance. Moreover, income data on individuals, collected by the government for tax purposes, may be used by insurers to monitor the earning capacity of individuals, and this may help limit moral hazard and cheating (Diamond, 1977). These observations, however, should not be equated with reasons why the government itself should operate insurance systems, or even make insurance mandatory. The tax measures just mentioned limit moral hazard regardless of who the insurer is; similarly, income data from tax collection may be supplied to private insurance companies, or even be made generally available (as they are, for instance, in Sweden).

In order to get a realistic perspective on the issues discussed above, it should also be kept in mind that several factors which create doubts about the viability of the social security benefits may also harm private solutions to income protection. For instance, negative macroeconomic shocks may lower the return on both private saving and private insurance 
policies. ${ }^{2}$ However, while households and insurance companies may minimize such risks by diversifying into an international portfolio, governments that run pay-as-you-go social security systems have to rely solely on the capacity of the domestic economy to pay taxes or compulsory fees. This means that benefits from a pay-as-you-go system may very well be more sensitive to domestic macroeconomic shocks than are claims on private insurance companies and pension funds that have diversified their portfolios internationally.

Governments may, of course, compensate for this sensitivity by exerting their power over fees and tax rates, but somebody in the domestic economy has to bear the risk of macroeconomic shocks. It is also easier for the government than for private insurance institutions to protect citizens against inflation risks, because of the absence, even today, of good hedges against inflation in financial markets.

This discussion illustrates the simple point that both private and government-operated income protection systems have severe limitations, and that these limitations are partly of a different nature in the two cases.

\section{Policy-induced market risk}

So far I have discussed how welfare state arrangements may lead to a replacement of market risks, i. e., uncertainty concerning endogenous variables of the economic system, by the risk of rules changes, i.e. increased uncertainty about exogenous data for the individual. Instability of rules will, however, also create new market risks, as disturbances from the political system are bound to influence people's behavior in various markets.

Some examples have already been mentioned. Job security legislation increases the unemployment risk for outsiders in the labor market. Price controls may create uncertainty about the availability of goods. For instance, rent control generate uncertainty about the possibilities of getting an appartment for those who do not already have one. Governmentprovision of services at controlled prices, possibly even zero-prices, generates a kind of "service lotteries" (stochastic rationing), etc.

One type of policy-induced market risk in the connection to welfare state policies is worth particular attention: changes in households' confidence in the viability of the social security system easily create instability in private saving behavior. There are at least two reasons for this. One is a simple wealth effect. Increased doubts about the viability of entitlements promised earlier mean that the expected wealth of the representative household suddenly goes down - assuming, realistically, that Ricardian equivalence does not hold. As a consequence, incentives are created for the household to restore at least part of its lost wealth, by saving a larger fraction of current income. In other words, when the household's resources for consumption in the future go down, the expected marginal utility of future consumption rises, which gives the household incentives to increase saving today. This wealth effect is simply a mirror image of the often asserted, and quite likely, tendency for household saving to fall after the introduction of comprehensive, and reliable, social security system. ${ }^{3}$

2 In the special case when pension funds for employees are managed by the production firms where they work (without reinsurance in an insurance company), the pension claims will, of course, be particularly uncertain.

${ }^{3}$ There has been considerable controversy in the literature over the effects of social security on private saving, due both to theoretical ambiguities (Feldstein, 1974), and to the difficulties of making 
The other reason for the household to increase its saving in response to rising uncertainty about the social security system is a more pure uncertainty effect: "prudence" induces households to respond to increased uncertainty by accumulating more private assets, even aside from the effects of a fall in the expected value of wealth. If there were no indivisabilities and irreversibilities in consumption (i.e., if there were only non-durables), the assertion that increased uncertainty generates higher saving is equivalent to assuming that the third derivative of the household utility function is positive - provided the second derivative is negative (Leland, 1968). It is not necessary to make this assumption, however, if we grant the existence of durable consumer goods, as these create indivisibilities and irreversibilities of spending decisions (Hassler, 1993). If the household becomes highly uncertain about its future income, it is hazardous to invest in durables, as the market value of such goods falls drastically after the investment has been made.

We may, heuristically, predict the household saving rate to be especially sensitive to changes in uncertainty in countries where welfare state entitlements are very generous, as households in such societies would be expected to hold particularly small amounts of financial assets, including private insurance policies and annuities. As an empirical illustration, the household saving rate in Sweden fell from about plus three percent of households' disposable income in 1960, when a new comprehensive pension system (ATP) was introduced, to about minus one percent in the mid-1970s. A further fall to minus five percent occurred in the mid-1980s (after a slight recovery in between), partly because the deregulation of credit markets made it possible for households to act according to the incentives created by the welfare state arrangements and the tax system, i.e., the incentives to incur debt. By contrast, along with increased uncertainty among households in the early 1990 s, the household saving rate suddenly jumped to about nine percent. Doubts about the viability of social security entitlements, accompanied by a drastic increase in unemployment, were probably two important factors behind this rise in uncertainty. ${ }^{4}$ This swing of the household saving rate of 14 percentage points corresponds to a fall in aggregate demand by about seven percent of GNP. This was, in fact, the single most important component of the huge reduction in aggregate demand for domestic output in Sweden at that time.

More generally, there is an obvious possibility that increased risks for households, either because of exogenous shocks such as higher unemployment, or because of increased doubts about the viability of the social security entitlements, will result in instability in the

convincing empirical studies in a world where many factors influence private saving. My own reading of the empirical evidence is that household saving is usually relatively low in countries where the pension system is characterized by both high pension benefits and wide coverage within the population; examples are Finland, the Netherlands, Norway and Sweden. By contrast, household saving is usually relatively high in countries with the opposite characteristics, such as Japan, the UK, Germany and Italy (see Ståhlberg, 1988, pp. 9-12). There are, however, countries that deviate from this general pattern, reflecting other factors that influence private saving.

4 There are also other explanations for the drastic rise in the private saving rate in Sweden. In the same way as the drop in the household saving rate in the second half of the $1980 \mathrm{~s}$ was, at least partly, caused by the boom in asset prices, the fall in asset prices in the early 1990 s, in connection with a huge rise in after-tax real interest rates, must have contributed to the subsequent rise in the saving rate. The 1991 tax reform also contributed to the rise in real after-tax interest rates. Interest costs can now be deducted against tax rates of only 30 percent, as compared to 50 percent immediately prior to the reform (and 72 percent in the early 1980 s for high-income groups). 
household saving rate, and that that this will destabilize the entire macroeconomy substantially, with huge increases in macroeconomic risks as a consequence. This is perhaps the most important example on policy-induced market risk.

\section{Policy options}

Rational income-protection policies should strike a balance (optimum) between risk reduction and other concerns, such as considerations of distribution and efficient incentives. It is, largely for distributional reasons, not desirable to let the individual endure all the consequences of his own, and "nature's" actions; nor is it, for efficiency reasons, desirable to lift away all risk from the individual, as various incentive problems, including moral hazard and cheating, may then become overwhelming.

The theoretical literature on principal-agents and moral hazard provides numerous suggestions for striking such a balance between conflicting concerns, by way of "optimal contracts" or "mechanism design" (Kreps, 1990). The suggestions are often quite complex, indeed much more complex than the attempted solutions which we find in the real world. This discrepancy between the theoretical literature and reality probably depends, to a large extent, on both the high information requirements of suggested solutions and on the administrative costs if they are implemented. Moreover, the methods suggested are often highly sensitive to the "environment" of individual agents and their assumed behavior patterns.

It is, for these reasons, probably advisable to continue to rely on quite simple, and hopefully rather robust mechanism when trying to strike a balance between risk reduction and other concern. The case for simplicity and robustness is perhaps even stronger for government-operated systems than for private systems, because of the sensitivity of government-operated systems to party politics and interest-group pressure.

How, then, could the uncertainties generated by the welfare state be mitigated without giving up much of either its contributions to reducing market uncertainty or its other important achievements, such as redistribution of wealth? Several alternative, or complementary, reforms are possible. Below is a brief sketch of both marginal and radical reforms. In each policy option, the ambitions is - as is usual when dealing with principal-agent problems - to create incentives for the potential beneficiaries to behave in ways preferred by provider of the benefits, i.e., in this case primarily the government but presumably indirectly also the voters. The basic ambition behind all the proposals is to make welfare state systems more viable, by reducing both rule instability and policy-induced market risk. Indeed, there is, in my judgment, a realistic possibility that the economic foundations of the welfare state will be undermined in some countries if reforms along these lines are not carried out rather soon.

\subsection{Marginal reforms}

4.1.1. One way of reducing rule instability may be to disconnect the social insurance system from the yearly budget process. This may be achieved by letting some semi-government agencies manage the systems, or even by allowing agencies outside the public sector to do so ; such reforms were, in fact, suggested by the Swedish so-called "Economy-Commission" in March 1993 (Lindbeck et al., 1993/1994).

The main hypothesis behind this proposal is that welfare state rules would become less vulnerable than they are today to recurring stabilization and redistribution policy interventions, ongoing political competition between parties, and the pressure of various interest 
groups. In the case of pay-as-you-go systems, the semi-independent agencies could be instructed to balance their accounts every year. So as to avoid large fluctuations in fees, there would, however, be a case for providing the agencies with some buffer funds (which may occasionally be negative, up to a fixed upper limit).

The basic welfare state rules would still be set by, and could therefore also be changed by, parliament. To enhance rule-stability, there may, however, be a case for requiring a qualified majority in parliament for changes in the rules.

4.1.2. Before such attempts are made to isolate the social security system from short-term politics, it is, however, important to revise the system - to minimize both moral hazard and outright cheating; otherwise the system may not be viable. The traditional way of achieving this is to provide only partial insurance, and hence to bring about a tradeoff between riskspreading and the provision of appropriate incentives. Co-insurance and deductibles are the standard techniques. Operationally, this means lower retention ratios or longer waiting periods for benefits; this would represent a shift away from all-encompassing protection, even against modest losses, to high-cost protection.

There is, however, also a case for more controls of the applicants for benefits. Indeed, there is in principle an optimum combination of incentives, in the form of coinsurance (or deductibles), and control (Lantto, 1991).

Reforms like these mean, of course, that total welfare state spending would be cut; i. e., there would be some "retreat" from the welfare state (Lindbeck, 1994a).

4.1.3. As the individual, through such reforms, would be forced to take a greater responsibility for his own economic security, we could expect additional voluntary insurance on top of the compulsory social security arrangements. But such voluntary insurance is far from unproblematic. We would run into a variant of the traditional problem of overinsurance, with external ("spillover") effects from one insurance institution to another, as it is the marginal effects of total insurance benefits that determine incentives. (This problem does not seem to be serious for the purchasers of old-age annuities, however, even though people are to some extent able to lengthen their expected life span by healthier habits).

To mitigate this problem, the government may impose a cap on the total benefit level. (This, of course, requires the providers of insurance to have information about the insurance policies that the individual has with other institutions.) In some cases, with recurring insurance outcomes such as in the case of short-term illness, it may alternatively be useful to require higher insurance fees for people who have also taken insurance elsewhere.

In order to avoid having some individuals move between different social insurance systems to get as much out of them as possible, it is also advisable to make the benefit levels the same in all parts of the system between which the individual can move at his own discretion.

4.1.4. Another way of improving the viability of various pay-as-you-go systems would be to make them more actuarial, so that the capital value of expected benefits for the individual conform better than today to the capital value of expected fees. The implicit tax wedges in the social security system would then be reduced, and the damage to economic incentives be minimized. It is important to realize that an actuarial system could still be "pay-as-yougo"; i. e., such a system does not have to be funded (Sheshinski and Weiss, 1981; Bröms, 
1990). If the pension system were transformed in this way, the current subsidization of early and partial retirement (for reasons other than disability) would automatically disappear.

We may also hypothesize that actuarially fair systems create stronger property rights than nonactuarial systems, as it is natural for citizens to regard benefits in the former type of systems as "earned" via previous work; pensions could then the regarded as postponed wages. Voters will perhaps be more upset if benefits are reduced in such systems than in a nonactuarial one. The advantage of strengthening the property rights in the social insurance systems is that such a reform would make it more difficult for politicians to disrupt the economic planning of the individual.

If, however, it turns out that the benefit systems already seriously damage the national economy, and politicians would therefore like to make cuts in the benefits levels, then strong, subjectively felt property rights in the benefits would instead be an obstacle for a better functioning national economy. The conclusion is that benefits should be cut down to "reasonable" (sustainable) levels before or at the same time as property rights in the entitlement systems are further strengthened.

The possibility of making social insurance systems more actuarial is probably greatest in the case of the pension system. But even a pension system cannot, in reality, be fully actuarial. Pooling of risks may, for administrative or distributional reasons, be necessary among groups with distinctly different (and known) risks, for instance, between men and women, and among people with different health records.

Shifts to more actuarial systems are even more difficult in other parts of the social security system. It may, however, be possible to take some steps in that direction in the case of, for instance, work-injury insurance, by way of experience-rates fees. Employers' fees in compulsory sick-pay insurance could also, in principle, be differentiated among firms with different absentee rates for (asserted) sickness. In both cases, the rationale would be to create incentives for firms to improve the working environment.

Increased actuarial elements could, at least technically, also be introduced to the unemployment insurance system, by differentiating payroll fees among industries, depending on the degree of cyclical instability of employment. The rationale would be to avoid subsidizing unstable sectors of the economy.

Even though these reforms might reduce the risks that the social security systems would break down because of various disincentive effects, the political feasibility of some of these reforms is controversial. Some people would certainly lose, and social insurance is an important tool of ex ante redistribution policy, which distinguishes it from private insurance (Atkinson, 1991).

Actuarial elements are even more difficult, perhaps impossible, to introduce for medical care and cash payments in connection with long-term sickness and permanent disability, due to overriding distributional considerations. Higher co-insurance or deductibles (i.e., high-cost protection), and stiffer medical tests and controls than today are probably the only feasible ways to deal with moral hazard and cheating in these systems. Moreover, even if it were decided to set up a more actuarial social security system, means-tested benefits would, of course, still be necessary for people with very low life-time income. Citizens with special needs, such as the handicapped, would as today need special benefits from the government. 
4.1.5. The types of reforms discussed so far to reduce the uncertainty about the welfare state rules do not prevent demographic and macroeconomic disturbances from causing changes in the relative distribution of per capita income between pensioners and the working population. It is likely, however, that citizens are more willing to accept relative redistribution of national income in actuarially fair systems, as existing benefits have then been "earned". If it is nevertheless regarded as desirable to mitigate such redistributions, one possibility would be to calculate the average pension benefits as a fraction of the contemporaneous average income of the working population, and to make each individual's pension proportional to his previously paid fees. (The same technique could, in principle, be used in some other social insurance systems.) However, the actuarial principle would then be considerably compromised, as the link between the capital value of expected fees and benefits would largely be broken.

\subsection{Radical reforms}

4.2.1. So far, I have only considered "marginal" improvements in the existing social security systems. A more radical reform would be to shift to funded social insurance systems. As in actuarially fair pay-as-you-go systems, tax wedges could then be avoided. Another conceivable advantage of a fully funded system is that property rights would perhaps be even stronger than in actuarially fair pay-as-you-go systems. But nothing is safe in this world, not even property rights in fully funded systems. Indeed, experience suggests that even in the case of funded private insurance policies, property rights are not always respected. Governments in some countries (including Denmark and Sweden) have, in fact, confiscated portions of private insurance capital by special tax levies in situations when politicians believed that the returns on the funds had been "too high" for a while.

There are also serious problems of transition if we want to move from a pay-as-you-go social security system to a fully funded system. One or several generations would have to pay "twice" - both for the pensions of their parents" generation and for their own pensions. Compromises are possible, however. Part of the compulsory pension fees could be deposited in funded system, including privately managed ones, whereas another part may be used by the pay-as-you-go system. A limited step in this direction will be taken in Sweden through the pension reform that was decided on (in principle) in 1994; two percentage points of the compulsory pension fees will be funded and managed by institutions of the insuree's own choice. Another possibility is to move slowly - during the course of many decades - from a pay-as-you-go to a fully funded system. Such a reform proposal has, in fact, been worked out by a Swedish insurance company (Skandia, 1991). A reform along these lines has already been enacted in Chile. If we want to preserve a decentralized market system, it is important to avoid that a shift to a funded system results in a de facto nationalization of pension funds; the administration of the funds has to be conducted outside the government sector, in funds of the individual's own choice.

4.2.2. An even more radical reform would be to give each individual, at birth, a "drawing right" on an account that he/she can use during his/her lifetime. (See Rehn, 1975; Fölster, 1994.) The account would become negative during periods of education early in life. It would subsequently be built up during workinglife, with the possibility of withdrawing funds from the account, up to a limit, for contingencies such as short-term sickness and unemployment. Whatever remains in the account when the individual reaches retirement age would be the basis for his pension. The viability of such system is enhanced for the same 
reasons as in the case of explicitly actuarial systems: the disincentive effects on the national economy would be minimized and the "property rights" probably boosted.

But a system with drawing rights has also serious limitations. It would have to be combined with components of high-cost insurance, which means that various elements of the existing social insurance system would have to be kept. Moreover, somebody would have to administer the funds that accumulate within the system. It may be difficult, perhaps impossible, to prevent politicians from taking over this task; hence, the system could easily develop into a huge nationalization of capital. These risks are, in my view, too great to take; I base this judgment on the attempts by some Swedish politicians and labor unions to create a system of fund-socialism. It is less risky to strive for a uniform and flexible reformed social security system by way of a better coordination of various elements of the present social security system.

4.2.3. Another radical reform - in quite a different direction than those discussed above would be to opt for a common safety net with the same benefit for everybody, for welldefined contigencies, such as old age, unemployment, disability, etc., combined with means-tested benefits ("social assistance"). It would then be left to the individual to organize income protection above the fixed safety net. The advantage of such a system is that it would be relatively inexpensive for the public sector, which would help create confidence in the viability of the system. However, as the fees would in this case function as pure taxes, disincentive effects on the national economy could not be avoided, by contrast to the situation in fully actuarial systems.

\section{Conclusion}

Where does all this lead us? In important respects, I have suggested that the social insurance system should take on various features of private insurance - more reliance on partial insurance by way of coinsurance of deductibles, methods to avoid overinsurance, more actuarial elements, more funded systems, etc. But we should also be clear about the limits of such "imports" of features from private insurance systems, as social insurance has ambitions quite separate from private insurance. One is to protect individuals against income uncertainty that is not insurable in an actuarial sense, such as the risk of obsolete skills; the welfare state, in fact, also insures against types of risks that may not even be contemplated in advance by individuals (Atkinson, 1991).

The ambition of the welfare state to redistribute wealth also limits the possibilities to differentiate the fees between risk groups. These redistributional ambitions are clearly illustrated by the fact that the bulk of the benefits from various social insurance systems, except from the pension system, is paid to a rather small group of the population. To a considerable extent, it is the same individuals who at different occasions during their lives receive sickpay, unemployment benefits and, later on, pension for disability and other forms of early retirement. For instance, a study for Sweden covering a period of 13 years indicates that the half of the population that was "cheapeast" for these systems received less than 6 percent of the total payments, while the most "expensive" decile received 48 percent of the payments. (See, En social försäkring, 1994, pp. 88-92).

It is also important that welfare state reforms conform with contemporary demands for greater flexibility in the working life of the individual. It is often argued that such demands are generated by the expansion of the service sector, by new organizational forms within 
firms, and by increased demand among individuals for flexible working arrangements. For instance, representatives of the Geneva Association on insurance (Giarini and Stahel, 1993, Chap. 3) argue that the individual may wish to abandon the "linear" life cycle that has so far been the rule - first education, subsequently work, and finally retirement. Such an observation, if correct, strengthens the case for a social security system that allows great flexibility as to when benefits are received during working life. Reforms in that direction would, however, also require a more flexible system of wage setting for the individual, so that, with increasing age, the individual gradually can reduce both working hours and the intensity of work, at the cost of a lower relative wage.

Perhaps a reasonable normative conclusion of the discussion in this paper is that we should opt for a combination of features from the various reform options discussed above. Such an eclectic system could consist of three different elements of income protection:

(a) A common safety net, for well-defined contingencies, at the bottom, perhaps providing the same benefits as in means-tested social assistance ;

(b) Additional benefits based on a compulsory, strongly actuarial pay-as-you-go system (i.e., benefits that rise strictly with previous income), combined with some funded elements and freedom for the individual to choose a fund manager; and finally,

(c) Large scope for voluntary saving and insurance on top of the compulsory system, though with a cap on total benefits.

Schematically, the suggested reforms are depicted in Figure 1. To satisfy increased demands for flexibility during the life-cycle, there is also a strong case for allowing the individual to draw on his/her pension benefits in advance (in an actuarial fashion) for studies, leisure periods or early retirement.

Since the risks in each of these three systems, as argued above, are far from fully correlated, the individual would enjoy a diversified portfolio of income protection systems. This is probably as far as we could reduce economic risk in a world with many kinds of uncertainties and different abilities of various institutions to cope with them.

\section{Acknowledgements}

I am grateful for comments on an earlier version by Karl Lantto, K. G. Scherman, Lars Söderström and Solveig Wikström. 


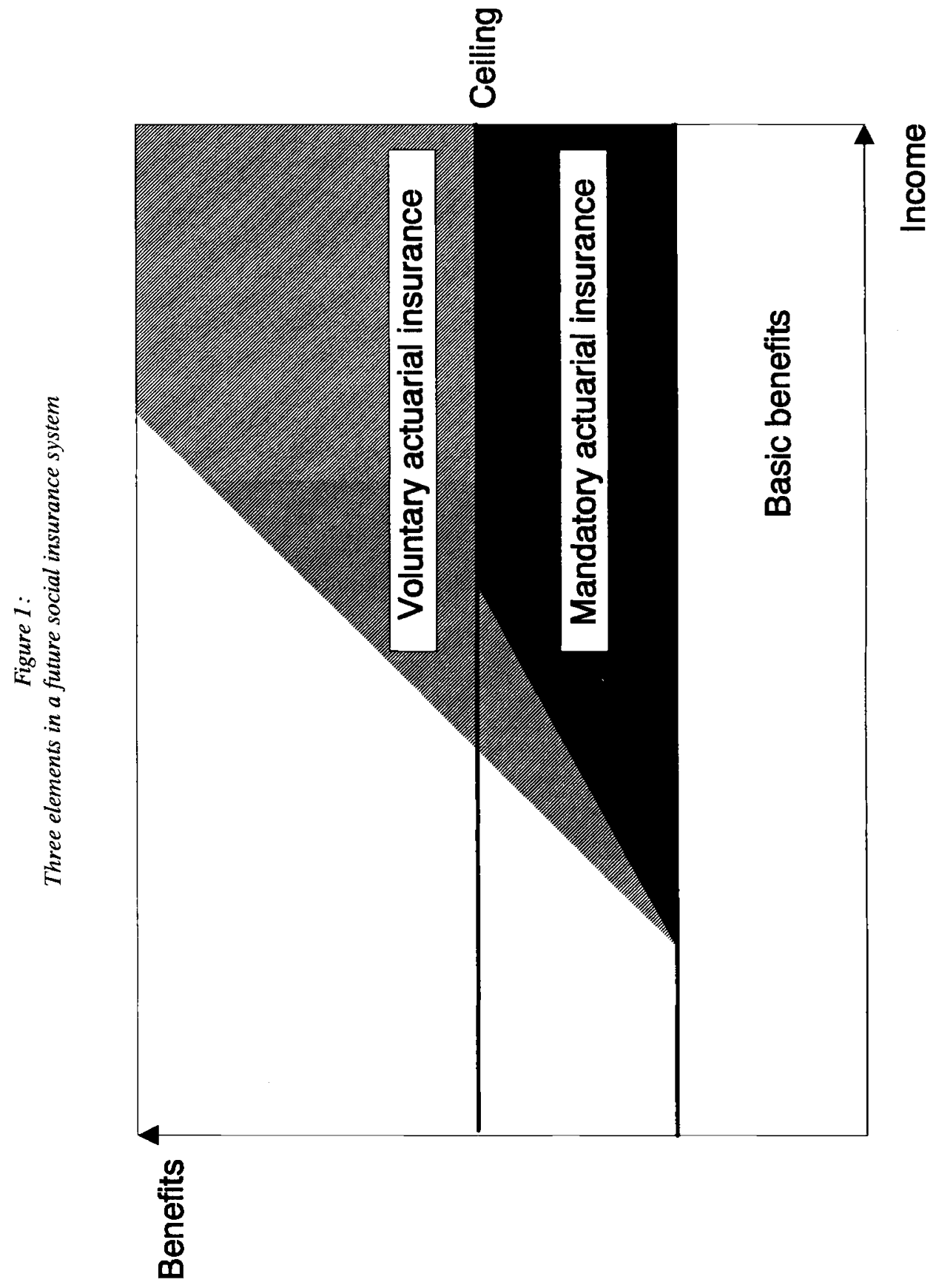




\section{REFERENCES}

ATKINSON, A. A. (1991): "Social Insurance", The Fifteenth Annual Lecture of the Geneva Association. The Geneva Papers on Risk and Insurance Theory 16(2), 113-141.

BRÖMS, J. (1990): Ur Askan av ATP (From the Ashes of the National Pension Scheme), Stockholm, SACO.

DIAMOND, P. A. (1977): “A Framework for Social Security Analysis“, Journal of Public Economics 8, 275-298.

En Social Försäkring (A Social Insurance), Rapport till expertgruppen för studier i offentlig ekonomi, Ds 1994: 81, Stockholm.

FELDSTEIN, M.S. (1974): "Social Security, Induced Retirement and Aggregate Capital Accumulation", Journal of Political Economy 87, 205-226.

FÖLSTER, S. (1994): “Socialförsäkring genom medborgarkonton: vilka är argumenten?" (Social Insurance by Way of Citizens' Accounts.) The Industrial Institute for Economic and Social Research, Working Paper No. 411, Stockholm.

GIARINI, O. and STAHEL, W. (1993): The Limits to Certainty, 2nd Edition, Dordrecht, Kluwer Academic Publishers.

HASSLER, J. (1993): "Variations in Risks - A Cause of Fluctuations in Demand". Institute for International Economic Studies, Seminar Paper No. 532, Stockholm University.

KREPS, D. M. (1990): A Course in Microeconomic Theory, Princeton N. J. and London, Princeton University Press and Harvester Wheatsheaf.

LANTTO, K. (1991): Optimal Deterrent to Malingiering, Economics Department, Stockholm University.

LELAND, H. (1968): "Saving and Uncertainty: The Precautionary Demand for Saving", Quarterly Journal of Economics, No. 3.

LINDBECK, A. (1994a): "Overshooting, Reform and Retreat of the Welfare State", The 1993 Tinbergen Lecture, De Economist 142, 1 - 19.

LINDBECK, A. (1994b): "Hazardous Welfare State Dynamics", Institute for International Economic Studies, Seminar Paper, Stockholm University.

LINDBECK, A. and SNOWER, D. (1988): The Insider-Outsider Theory of Employment and Unemployment, Cambridge MA, MIT Press.

LINDBECK, A., MOLANDER, P., PERSSON, T., PETTERSON, O., SANDMO, A., SWEDENBORG, B. and THYGESEN, N. (1994): Turning Sweden Around, Cambridge MA, MIT Press. (Original Swedish version, 1993).

REHN, G. (1975): "Flextid och flexliv" (Flex-time and flex-life), Economisk Debatt No. 1, 72-88.

SAMUELSON, P. A. (1958): "An Exact Consumption-Income Model of Interest with and without the Social Contrivance of Money", Journal of Political Economy 66 (6), December, 467-482.

SHESHINSKI, E. and WEISS, Y. (1981): "Uncertainty and Optimal Social Security Systems", Quarterly Journal of Economics 96, 189-206.

SKANDIA, ATP $i$ Nytt Ljus (1993): (The National Pension Scheme in a New Light), Skandia Insurance Company, Stockholm.

STÅHLBERG, A.-Ch. (1988): Pensionssparandets Inverkan på Hushållens Sparande (The Effects of Pension Saving on Houshold Saving), Expert Report, Spardelegationen.

TOBIN, J. (1970): "On Limiting the Domain of Inequality", Journal of Law and Economics 13, 263 272.

VARIAN, H. (1980): "Redistributive Taxation as Social Insurance", Journal of Public Economics 14, $44-68$. 